Supporting information:

\title{
Electrochemically induced precipitation enables fresh urine stabilization and facilitates source separation
}

Jolien De Paepe ${ }^{a, b, c}$, Laurens De Pryck ${ }^{a}$, Arne Verliefde $^{c, d}$, Korneel Rabaey ${ }^{a, c *}$ \& Peter Clauwaert ${ }^{a, c}$

a Center for Microbial Ecology and Technology (CMET), Faculty of Bioscience Engineering - Ghent University, Coupure Links 653, 9000 Gent, Belgium

b Department d'Enginyeria Química, Biològica i Ambiental - Universitat Autònoma de Barcelona, Bellaterra 08193 Barcelona, Spain

c Center for Advanced Process Technology and Urban Resource Efficiency (CAPTURE, www.captureresources.be)

d Particle and Interfacial Technology Group (Palnt), Faculty of Bioscience Engineering - Ghent University, Coupure Links 653, 9000 Gent, Belgium

* Corresponding author: Korneel.Rabaey@UGent.be;

The supporting information contains 15 pages including 8 figures and 4 tables. 


\section{A. Experimental setup}

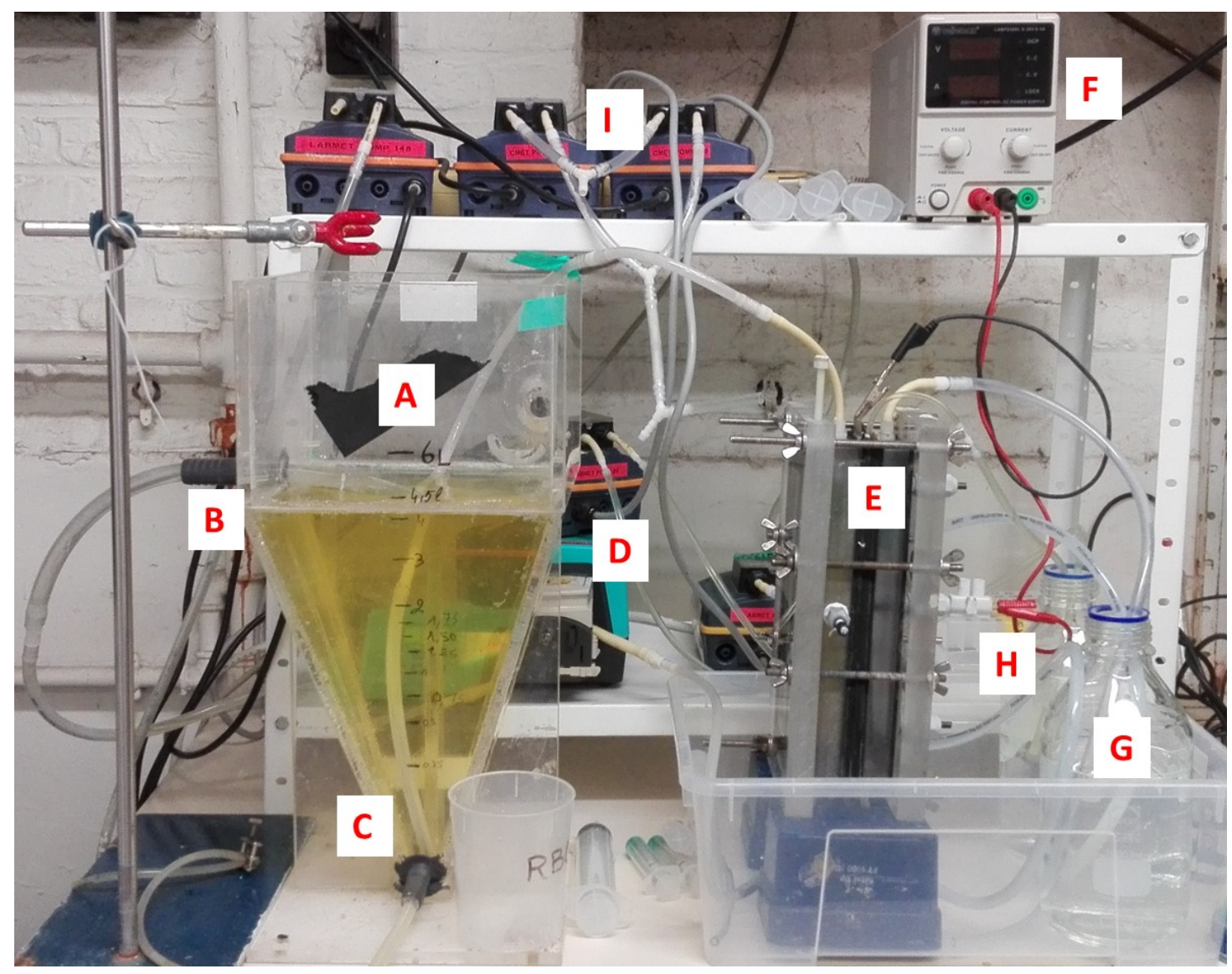

Figure S1. Experimental setup (with three-chamber cell)

A: crystallizer (decanter with active volume of $4 \mathrm{~L}$ )

$\mathrm{B}$ : inlet recirculation loop crystallizer (at the top of the crystallizer)

C: outlet recirculation loop crystallizer (at the bottom of the crystallizer)

D: recirculation pump (Watson Marlow 323E/D, MA, USA)

E: electrochemical cell

F: digital-control DC power supply (LABPS3005, Velleman, Gavere, Belgium)

G: recirculation vessel anolyte

$\mathrm{H}$ : recirculation vessel middle compartment solution

I: recirculation pumps anodic and middle compartment (DULCOßflex DF2a, ProMinent GmbH, Heidelberg, Germany) 

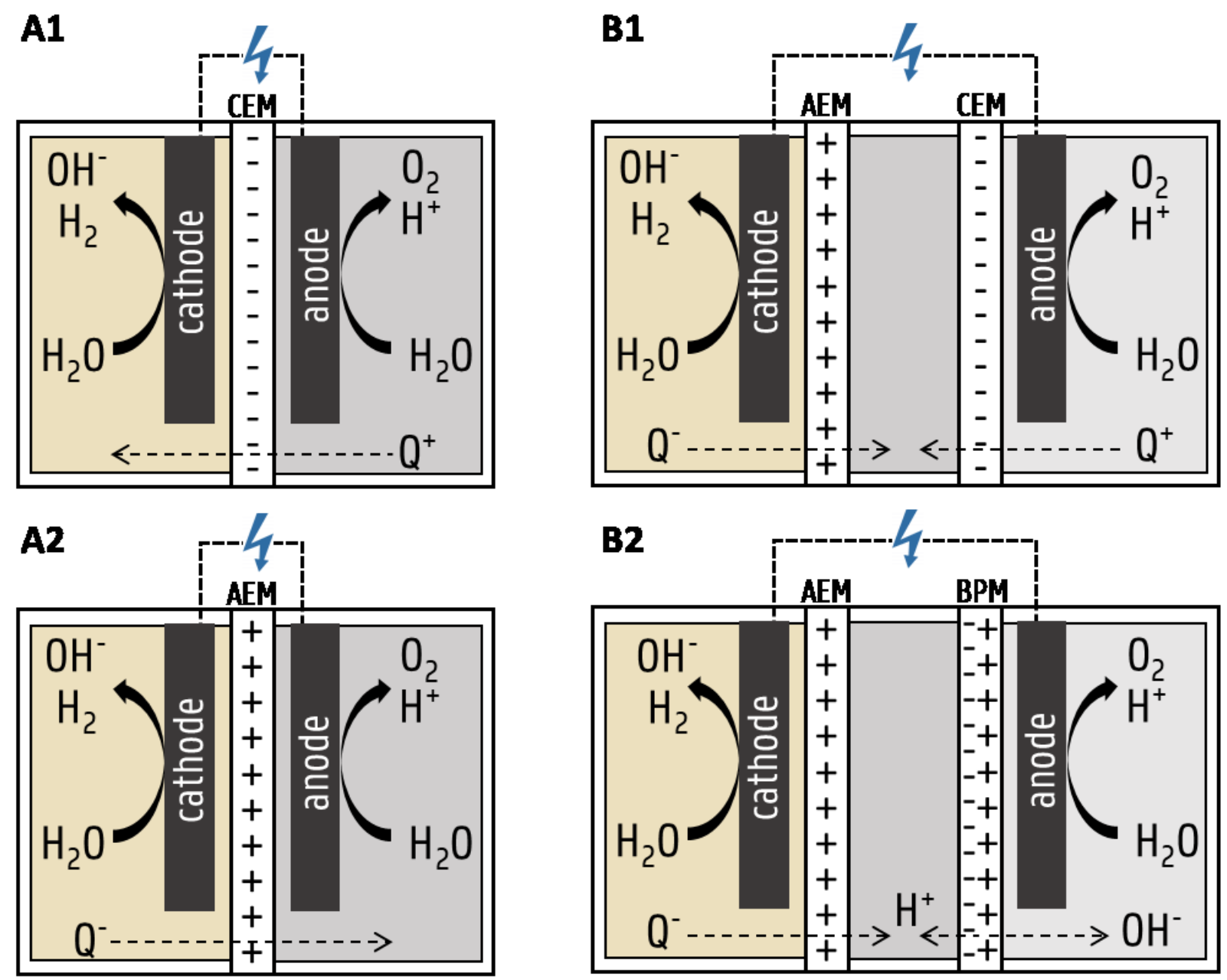

Figure S2. Schematic overview of the four configurations: CEM (A1), AEM+CEM (B1), AEM (A2) and AEM+BPM (B2). The arrows show the direction of the electromigration. 
Table S1. Urine composition after dilution with demineralized water. $A V=$ average, $S D=$ standard deviation.

\begin{tabular}{|c|c|c|c|c|c|c|c|c|c|c|}
\hline \multirow[t]{2}{*}[\mathrm{mmol}\mathrm{L}^{-1}]{} & \multicolumn{5}{|c|}{ AEM } & \multicolumn{5}{|c|}{ CEM } \\
\hline & 1 & 2 & 3 & AV & SD & 1 & 2 & 3 & AV & SD \\
\hline $\mathrm{Cl}^{-}$ & 44.0 & 34.1 & 33.6 & 37.3 & 5.9 & 37.0 & 43.8 & 42.7 & 41.2 & 3.6 \\
\hline $\mathrm{PO}_{4}{ }^{3-}$ & 2.7 & 3.1 & 2.6 & 2.8 & 0.3 & 2.4 & 4.0 & 3.0 & 3.1 & 0.8 \\
\hline $\mathrm{SO}_{4}{ }^{2-}$ & 3.1 & 2.7 & 2.9 & 2.9 & 0.2 & 3.2 & 3.8 & 3.8 & 3.6 & 0.3 \\
\hline $\mathrm{Na}^{+}$ & 34.3 & 29.6 & 23.1 & 29.0 & 5.6 & 33.2 & 37.8 & 32.1 & 34.4 & 3.0 \\
\hline $\mathrm{NH}_{4}^{+}$ & 22.6 & 11.0 & 17.4 & 17.0 & 5.8 & 10.7 & 10.8 & 6.6 & 9.4 & 2.4 \\
\hline $\mathrm{K}^{+}$ & 20.6 & 14.8 & 15.3 & 16.9 & 3.2 & 15.6 & 20.3 & 16.2 & 17.4 & 2.6 \\
\hline $\mathrm{Ca}^{2+}$ & 0.8 & 0.4 & 0.4 & 0.5 & 0.2 & 0.6 & 0.9 & 0.9 & 0.8 & 0.1 \\
\hline $\mathrm{Mg}^{2+}$ & 0.9 & 0.7 & 0.5 & 0.7 & 0.2 & 0.6 & 1.0 & 0.8 & 0.8 & 0.2 \\
\hline \multirow[t]{2}{*}[\mathrm{mmol}\mathrm{L}^{-1}]{} & \multicolumn{5}{|c|}{ CEM+AEM } & \multicolumn{5}{|c|}{ AEM+BPM } \\
\hline & 1 & 2 & 3 & AV & SD & 1 & 2 & 3 & AV & SD \\
\hline $\mathrm{Cl}^{-}$ & 38.5 & 32.1 & 49.0 & 39.9 & 8.5 & 58.3 & 60.7 & 38.9 & 52.6 & 12.0 \\
\hline $\mathrm{PO}_{4}{ }^{3-}$ & 3.9 & 2.7 & 3.9 & 3.5 & 0.7 & 3.5 & 3.8 & 1.6 & 3.0 & 1.2 \\
\hline $\mathrm{SO}_{4}{ }^{2-}$ & 4.2 & 2.7 & 3.5 & 3.5 & 0.7 & 3.4 & 3.9 & 2.8 & 3.4 & 0.5 \\
\hline $\mathrm{Na}^{+}$ & 26.3 & 27.1 & 36.8 & 30.1 & 5.8 & 40.7 & 46.3 & 56.9 & 48.0 & 8.2 \\
\hline $\mathrm{NH}_{4}^{+}$ & 7.9 & 7.7 & 6.7 & 7.5 & 0.6 & 5.7 & 13.8 & 14.5 & 11.3 & 4.9 \\
\hline $\mathrm{K}^{+}$ & 23.7 & 19.3 & 22.6 & 21.9 & 2.3 & 19.8 & 26.8 & 17.6 & 21.4 & 4.8 \\
\hline $\mathrm{Ca}^{2+}$ & 1.2 & 1.0 & 1.2 & 1.1 & 0.1 & 1.2 & 1.0 & 1.3 & 1.2 & 0.1 \\
\hline $\mathbf{M g}^{2+}$ & 1.3 & 0.9 & 1.3 & 1.2 & 0.2 & 0.9 & 0.8 & 0.9 & 0.9 & 0.1 \\
\hline
\end{tabular}




\section{B. Electric charge and electrode energy consumption}

\section{Cell potential}

The cell potential depends on the $\mathrm{pH}$ in the compartments and can be calculated with the Nernst equation. The $\mathrm{pH}$ of the catholyte (urine) increased from $\sim 7$ to $\sim 11$, while the $\mathrm{pH}$ of the anolyte decreased from $\sim 5$ to $\sim 2$ (Appendix, Section D, Table S2).

cathode reaction: $2 \mathrm{H}_{2} \mathrm{O}+2 \mathrm{e}^{-} \rightarrow \mathrm{H}_{2}+2 \mathrm{OH}^{-}$

$$
E^{0}(S H E)=-0.8277 \mathrm{~V}
$$

- $\mathrm{pH} 7\left(\left[\mathrm{OH}^{-}\right]=10^{-7} \frac{\mathrm{mol}}{\mathrm{L}}, p_{\mathrm{H}_{2}}=1 \mathrm{bar}\right): E_{\mathrm{C}}=-0.8277 \mathrm{~V}-\frac{0.059 \mathrm{~V}}{2} \log \frac{1 *\left(10^{-7}\right)^{2}}{1}=-0.4147 \mathrm{~V}$

- $\mathrm{pH} 11\left(\left[\mathrm{OH}^{-}\right]=10^{-3} \frac{\mathrm{mol}}{\mathrm{L}}, p_{\mathrm{H}_{2}}=1 \mathrm{bar}\right): E_{\mathrm{C}}=-0.8277 \mathrm{~V}-\frac{0.059 \mathrm{~V}}{2} \log \frac{1 *\left(10^{-3}\right)^{2}}{1}=-0.6507 \mathrm{~V}$

anode reaction: $2 \mathrm{H}_{2} \mathrm{O} \rightarrow \mathrm{O}_{2}+4 \mathrm{H}^{+}+4 \mathrm{e}^{-}$

$$
\mathrm{E}^{0}(\mathrm{SHE})=1.229 \mathrm{~V}
$$

- $\mathrm{pH} 5\left(\left[\mathrm{H}^{+}\right]=10^{-5} \frac{\mathrm{mol}}{\mathrm{L}}, p_{\mathrm{O}_{2}}=1 \mathrm{bar}\right): E_{a}=1.229 \mathrm{~V}-\frac{0.059 \mathrm{~V}}{4} \log \frac{1}{1 *\left(10^{-5}\right)^{4}}=0.934 \mathrm{~V}$

- $\mathrm{pH} 2\left(\left[\mathrm{H}^{+}\right]=10^{-2} \frac{\mathrm{mol}}{\mathrm{L}}, p_{O_{2}}=1 \mathrm{bar}\right): E_{a}=1.229 \mathrm{~V}-\frac{0.059 \mathrm{~V}}{4} \log \frac{1}{1 *\left(10^{-2}\right)^{4}}=1.052 \mathrm{~V}$

cell potential:

- $\quad$ start (pH 7-5): $E_{\text {cell }}=E_{a}-E_{c}=0.934-(-0.4147)=1.3487 \mathrm{~V}$

- $\quad$ end $(\mathrm{pH} 11-2): E_{c e l l}=E_{a}-E_{c}=1.052-(-0.6507)=1.7027 \mathrm{~V}$ 
Table S2. Electric charge and electrode energy consumption. The electric charge [Coulomb] was calculated by multiplying the applied current $(0.6 \mathrm{~A})$ with the time needed to reach the $\mathrm{pH}$ setpoint (in seconds). The theoretical electrochemical energy consumption (electrical input to the electrochemical cell) was calculated by multiplying the cell potential to drive the water reduction/oxidation reactions $(1.5 \mathrm{~V}$, see page $\mathrm{S} 4)$ with the current density to reach $\mathrm{pH} 11$ or 12 [C $\mathrm{L}^{-1}$ urine], devided by 3600 (to convert seconds into hour). The electrochemical energy consumption was calculated in the same way, but with the average (measured) cell voltage instead of the theoretical cell potential. $\mathrm{AV}=$ average, $\mathrm{SD}=$ standard deviation, $\mathrm{Wh}_{\mathrm{el}}=$ electrical energy

\begin{tabular}{lccccccccccccc}
\hline & \multicolumn{1}{c}{} & CEM & \multicolumn{1}{c}{} & \multicolumn{3}{c}{ AEM } & \multicolumn{4}{c}{ AEM+CEM } & \multicolumn{3}{c}{ AEM+BPM } \\
\hline & AV & & SD & AV & & SD & AV & & SD & AV & & SD \\
\hline current applied [A] & 0.6 & \pm & 0.0 & 0.6 & \pm & 0.0 & 0.6 & \pm & 0.0 & 0.6 & \pm & 0.0 \\
average cell voltage [V] & 4.5 & \pm & 0.1 & 7.5 & \pm & 1.1 & 7.6 & \pm & 1.4 & 7.4 & \pm & 0.8 \\
pH start & 6.8 & \pm & 0.1 & 7.0 & \pm & 0.3 & 7.0 & \pm & 0.2 & 6.7 & \pm & 0.2 \\
pH end (11) & 11.1 & \pm & 0.1 & 11.2 & \pm & 0.3 & 11.1 & \pm & 0.1 & 11.1 & \pm & 0.3 \\
pH end (12) & & & & & & & 12.1 & \pm & 0.0 & 12.0 & \pm & 0.2 \\
time to pH 11 [h] & 3.6 & \pm & 0.6 & 3.3 & \pm & 0.5 & 3.8 & \pm & 0.7 & 4.0 & \pm & 1.2 \\
time to pH 12 [h] & & & & & & & 6.4 & \pm & 0.9 & 6.4 & \pm & 0.6 \\
\hline
\end{tabular}

\section{Electric charge to reach $\mathrm{pH} 11$ or 12}

$\mathrm{pH} 11$

\begin{tabular}{|c|c|c|c|c|c|c|c|c|c|c|c|c|}
\hline$[\mathrm{kC}]$ & 7.79 & \pm & 1.30 & 7.25 & \pm & 1.08 & 8.26 & \pm & 1.46 & 8.67 & \pm & 2.63 \\
\hline$\left[\mathrm{kC} \mathrm{L}^{-1}\right]^{*}$ & 1.95 & \pm & 0.33 & 1.81 & \pm & 0.27 & 2.07 & \pm & 0.36 & 2.167 & \pm & 0.66 \\
\hline$\left[\mathrm{kC} \mathrm{L}^{-1} \text { urine }\right]^{\star *}$ & 3.90 & \pm & 0.65 & 3.62 & \pm & 0.54 & 4.13 & \pm & 0.73 & 4.334 & \pm & 1.31 \\
\hline \multicolumn{13}{|l|}{$\mathrm{OH} 12$} \\
\hline$[\mathrm{kC}]$ & & & & & & & 13.86 & \pm & 2.03 & 13.86 & \pm & 1.40 \\
\hline$\left[\mathrm{kC} \mathrm{L}^{-1}\right]^{*}$ & & & & & & & 3.47 & \pm & 0.51 & 3.47 & \pm & 0.35 \\
\hline$\left[\mathrm{kC} \mathrm{L}^{-1} \text { urine }\right]^{* *}$ & & & & & & & 6.93 & \pm & 1.02 & 6.93 & \pm & 0.70 \\
\hline
\end{tabular}

\section{Theoretical electrochemical energy consumption}

$\begin{array}{lllll}\text { cell potential }[\mathrm{V}] & 1.5 & 1.5 & 1.5 & 1.5\end{array}$

$\mathrm{pH} 11$

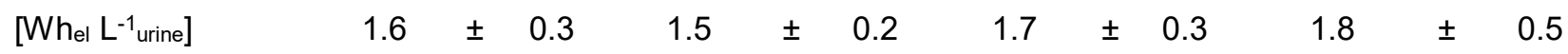

$\mathrm{pH} 12$

[Whel L-1 urine]

$\begin{array}{r}2.9 \pm 0.0 \quad 2.9 \pm \quad \pm \quad 0.0 \\ \hline\end{array}$

\section{Real electrochemical energy consumption}

$\mathrm{pH} 11$

\begin{tabular}{|c|c|c|c|c|c|c|c|c|c|c|c|c|}
\hline [Whel $\mathrm{L}^{-1}$ urine] & 4.9 & \pm & 0.7 & 7.6 & \pm & 1.7 & 8.6 & \pm & 1.9 & 8.8 & \pm & 2.4 \\
\hline $\mathrm{pH} 12$ & & & & & & & & & & & & \\
\hline [Whel $\mathrm{L}^{-1}$ urine] & & & & & & & 14.4 & \pm & 2.5 & 14.3 & \pm & 2.4 \\
\hline
\end{tabular}

* volume of crystallizer $=4 \mathrm{~L}$

${ }^{* *}$ volume of urine $=2 \mathrm{~L}$ (urine dilution $\left.=1: 1(50 \%)\right)$ 


\section{Bivalent cation removal}
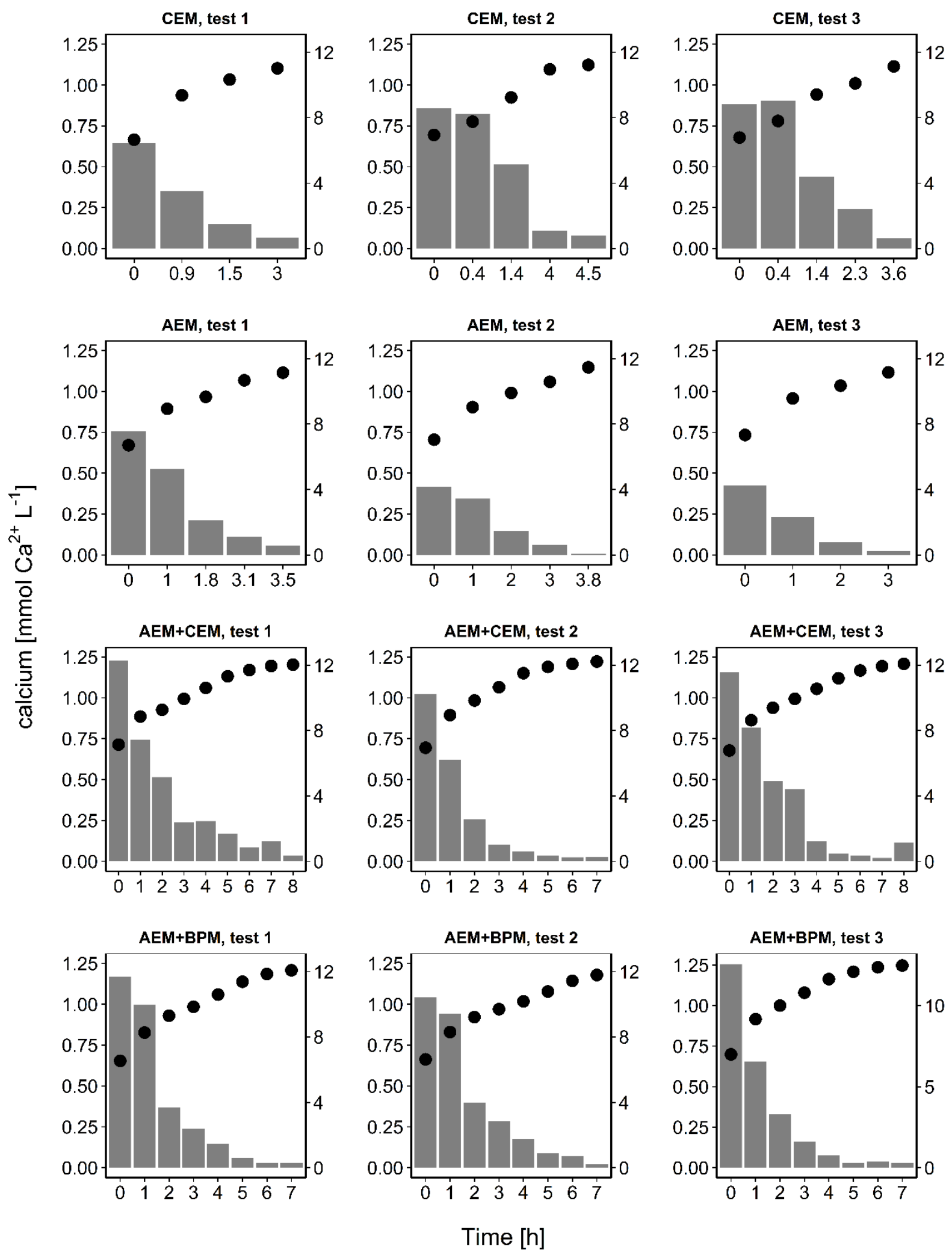

Figure S3. Calcium concentration in the crystallizer. The black dots display the corresponding $\mathrm{pH}$ in the crystallizer (secondary $y$-axis). 

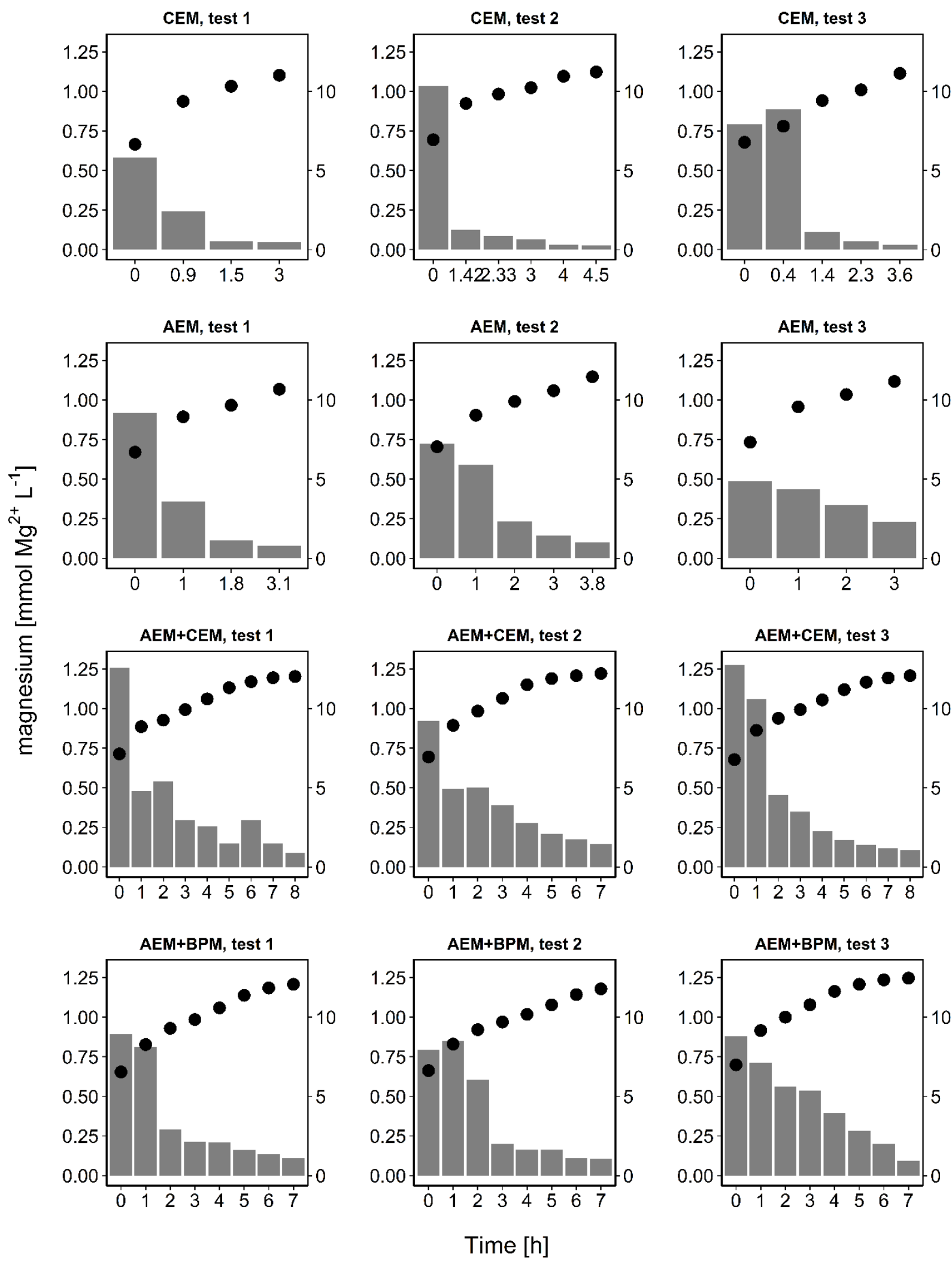

Figure S4. Magnesium concentration in the crystallizer. The black dots display the corresponding $\mathrm{pH}$ in the crystallizer (secondary y-axis). 


\section{Electromigration}

\section{$\underline{\text { Calculations }}$}

Based on the electric charge that was applied during the test, the amount of electrons that went from the anode to the cathode was determined as follows:

$$
\left[\text { mmol } e^{-}\right]=\frac{\text { time }[s] * \text { current }[A]}{96485.3 \frac{C}{\text { mol } e^{-}}} * 10^{3}
$$

An equal amount of charge should migrate between the compartments to restore the electroneutrality of the system. For the AEM, the relative contribution of chloride, sulfate, nitrate and phosphate to the total migration was calculated as follows:

relative contribution $[\%]$

$$
=\frac{\left(Q_{p H_{11}}^{-}\left[\frac{m g}{L}\right]-Q_{t_{0}}^{-}\left[\frac{m g}{L}\right]\right) * V_{\text {middle compartment }}[L] * \text { valence of ion }}{M M\left[\frac{m g}{m m o l}\right] * \text { amount of electrons }\left[\text { mmol } e^{-}\right]} * 100
$$

with

- $Q_{p H_{11}}^{-}\left[\frac{\mathrm{mg}}{\mathrm{L}}\right]=$ concentration of anion in middle compartment at the end of the test (when the $\mathrm{pH}$ in the crystallizer equaled 11)

- $Q_{t_{0}}^{-}\left[\frac{\mathrm{mg}}{\mathrm{L}}\right]=$ concentration of anion in middle compartment at the start of the test

- $\quad V_{\text {middle compartment }}[L]=$ volume of the middle compartment

- valence of ion $=-1$ for chloride and nitrate, -2 for sulfate and phosphate $\left(\mathrm{HPO}_{4}{ }^{2-}\right.$ is the dominating speciation between $\mathrm{pH} 7-12$ )

- $\quad M M\left[\frac{\mathrm{mg}}{\mathrm{mmol}}\right]=$ molar mass of ion

- amount of electrons $\left[\mathrm{mmol} \mathrm{e}^{-}\right]=$amount of electrons that were transferred from anode to cathode 
For the CEM, the relative contribution of sodium and protons to the total migration were calculated as follows:

relative contribution of sodium [\%]

$$
=\frac{\left(N a_{p H_{11}}^{+}\left[\frac{m g}{L}\right]-N a_{t_{0}}^{+}\left[\frac{m g}{L}\right]\right) * V_{\text {anodic compartment }}[L] * \text { valence of ion }}{M M\left[\frac{m g}{m m o l}\right] * \text { amount of electrons }\left[\text { mmol } e^{-}\right]} * 100
$$

with

- $\quad N a_{p H_{11}}^{+}\left[\frac{\mathrm{mg}}{\mathrm{L}}\right]=$ sodium concentration in the anodic compartment at the end of the test (when the $\mathrm{pH}$ in the crystallizer equaled 11)

- $N a_{t_{0}}^{+}\left[\frac{m g}{L}\right]=$ sodium concentration in the anodic compartment at the start of the test

- $\quad V_{\text {anodic compartment }}[L]=$ volume of the anodic compartment

- valence of ion $=+1$

- $\quad M M\left[\frac{m g}{m m o l}\right]=$ molar mass of sodium

- amount of electrons $\left[\mathrm{mmol}^{-}\right]=$amount of electrons that were transferred from anode to cathode

relative contribution of protons $[\%]=100$ - relative contribution of sodium

Since no sodium migrated from the anodic compartment to the middle compartment in the AEM+BPM configuration, it was assumed that protons accounted for $100 \%$ of the migration. 
Table S3. Electrical conductivity, pH, removal percentages in the crystallizer and contribution of each ion to the total electromigration. The removal percentages in the crystallizer are calculated by dividing the difference in concentration between the start and the end $(\mathrm{pH} 11)$ of the experiment by the initial concentration in the crystallizer. Positive values indicate that the ion is removed from the urine (due to migration and/or precipitation). Negative values indicate an increase in concentration. Other anions include anions that were not quantified (including hydroxyl ions, carbonate ions and negatively charged organics). About $7 \%$ of the COD migrated through the AEM. $\mathrm{AV}=$ average, $\mathrm{SD}=$ standard deviation

\begin{tabular}{|c|c|c|c|c|c|c|c|c|c|c|c|c|c|}
\hline & & \multicolumn{3}{|c|}{ CEM } & \multicolumn{3}{|c|}{ AEM } & \multicolumn{3}{|c|}{ AEM+CEM } & \multicolumn{3}{|c|}{ AEM+BPM } \\
\hline & & AV & & SD & AV & & $\mathrm{SD}$ & AV & & SD & AV & & $\mathrm{SD}$ \\
\hline \multicolumn{14}{|c|}{ electrical conductivity (EC) } \\
\hline \multirow[t]{2}{*}{ crystallizer } & start & 8.0 & \pm & 1.1 & 8.0 & \pm & 1.1 & 6.9 & \pm & 1.8 & 9.2 & \pm & 2.7 \\
\hline & end & 9.0 & \pm & 1.2 & 7.5 & \pm & 0.6 & 6.1 & \pm & 1.4 & 8.0 & \pm & 2.9 \\
\hline \multirow[t]{2}{*}{ anolyte } & start & 34.3 & \pm & 0.8 & 12.5 & \pm & 0.3 & 8.8 & \pm & 0.1 & 9.9 & \pm & 0.8 \\
\hline & end & 38.7 & \pm & 0.3 & 22.7 & \pm & 1.7 & 15.9 & \pm & 0.5 & 10.1 & \pm & 1.8 \\
\hline \multirow[t]{2}{*}{ middle compartment } & start & & & & & & & 8.6 & \pm & 0.3 & 9.7 & \pm & 1.0 \\
\hline & end & & & & & & & 20.4 & \pm & 2.1 & 32.9 & \pm & 12.2 \\
\hline \multicolumn{14}{|l|}{ pH } \\
\hline \multirow[t]{2}{*}{ anolyte } & start & 3.9 & \pm & 0.3 & 5.8 & \pm & 2.5 & 5.1 & \pm & 2.2 & 5.2 & \pm & 0.6 \\
\hline & end & 2.1 & \pm & 0.0 & 1.8 & \pm & 0.1 & 1.3 & \pm & 0.2 & 3.2 & \pm & 0.2 \\
\hline \multirow[t]{2}{*}{ middle compartment } & start & & & & & & & 5.0 & \pm & 2.4 & 4.8 & \pm & 1.0 \\
\hline & end & & & & & & & 1.2 & \pm & 0.2 & 1.1 & \pm & 0.2 \\
\hline \multicolumn{14}{|c|}{ removal percentages in the crystallizer } \\
\hline chloride [\%] & & 0.8 & \pm & 8.1 & 30.0 & \pm & 3.5 & 31.6 & \pm & 2.3 & 34.6 & \pm & 7.3 \\
\hline sulfate [\%] & & 13.4 & \pm & 3.4 & 25.5 & \pm & 7.9 & 29.1 & \pm & 1.0 & 29.4 & \pm & 10.3 \\
\hline nitrate [\%] & & & & & & & & 26.8 & \pm & 3.9 & 30.4 & \pm & 4.9 \\
\hline phosphate [\%] & & 34.7 & \pm & 5.7 & 43.9 & \pm & 15.6 & 52.0 & \pm & 1.4 & 59.7 & \pm & 16.7 \\
\hline precipitation [\%] & & 34.7 & \pm & 5.7 & 34.2 & \pm & 15.8 & 36.8 & \pm & 1.9 & 48.2 & \pm & 14.9 \\
\hline sodium [\%] & & -29.5 & \pm & 31.2 & -6.6 & \pm & 1.7 & -16.0 & \pm & 8.6 & -5.7 & \pm & 12.4 \\
\hline potassium [\%] & & 1.2 & \pm & 14.2 & -2.1 & \pm & 15.0 & -7.3 & \pm & 3.9 & -2.7 & \pm & 34.3 \\
\hline \multicolumn{14}{|l|}{ migration } \\
\hline \multicolumn{14}{|l|}{ AEM } \\
\hline chloride [\%] & & & & & 54.9 & \pm & 5.2 & 54.6 & \pm & 3.4 & 56.6 & \pm & 3.5 \\
\hline nitrate [\%] & & & & & & & & 0.5 & \pm & 0.1 & 0.4 & \pm & 0.1 \\
\hline phosphate [\%] & & & & & 2.8 & \pm & 0.3 & 4.6 & \pm & 0.6 & 2.7 & \pm & 0.6 \\
\hline sulfate [\%] & & & & & 7.8 & \pm & 3.3 & 17.7 & \pm & 5.6 & 22.3 & \pm & 14.0 \\
\hline other anions [\%] & & & & & 34.4 & \pm & 5.0 & 23.2 & \pm & 8.7 & 18.1 & \pm & 17.3 \\
\hline \multicolumn{14}{|l|}{ CEM/BPM } \\
\hline sodium [\%] & & 92.4 & & & & & & 33.7 & \pm & 5.7 & 0.0 & \pm & 0.0 \\
\hline protons [\%] & & 7.6 & & & & & & 66.3 & \pm & 5.7 & 100.0 & \pm & 0.0 \\
\hline
\end{tabular}



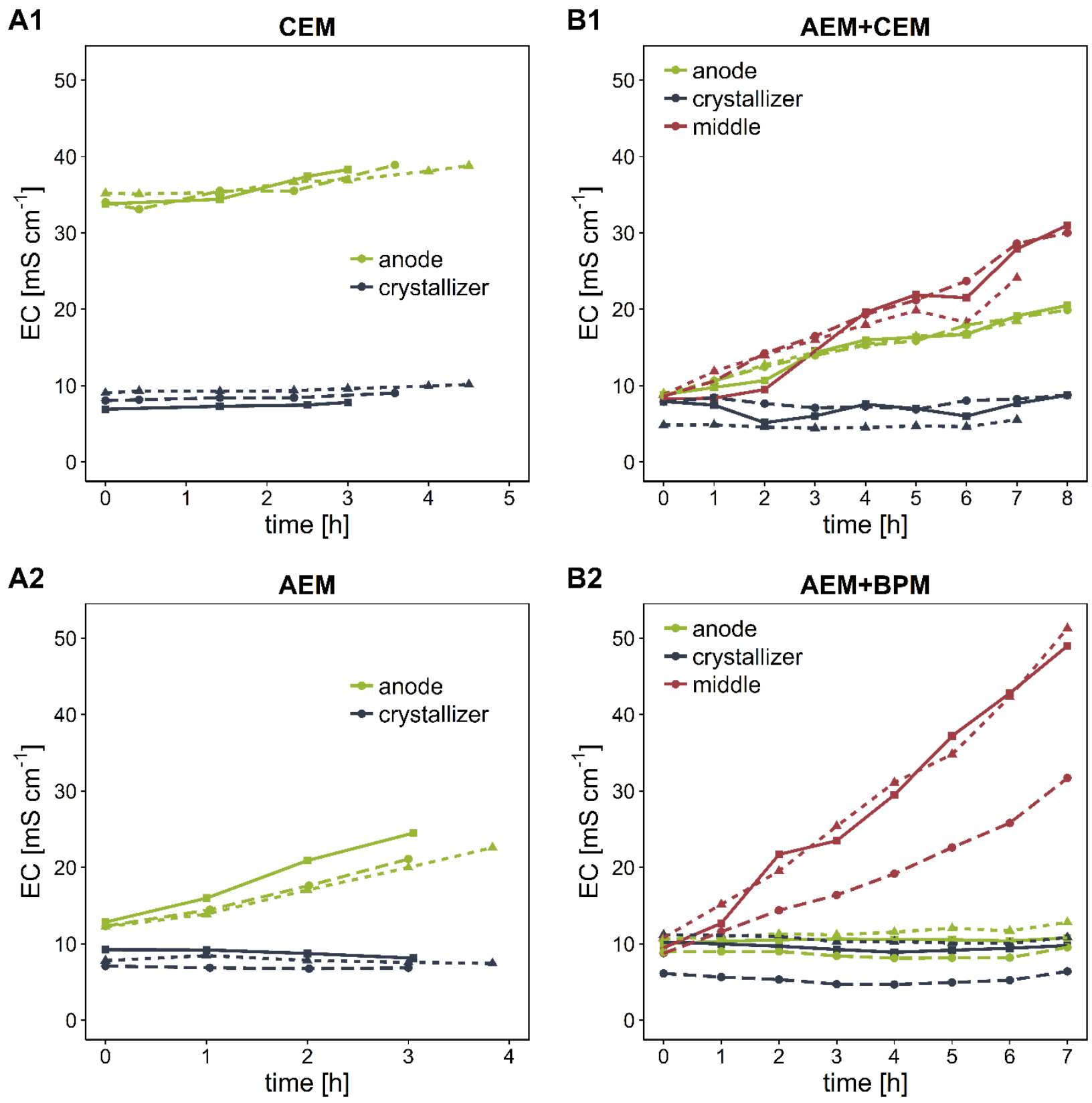

Figure S5. Electrical conductivity in the four configurations: CEM (A), AEM+CEM (B), AEM (C) and AEM+BPM (D). Each configuration was tested in triplicate (indicated with different symbols and linetypes). 


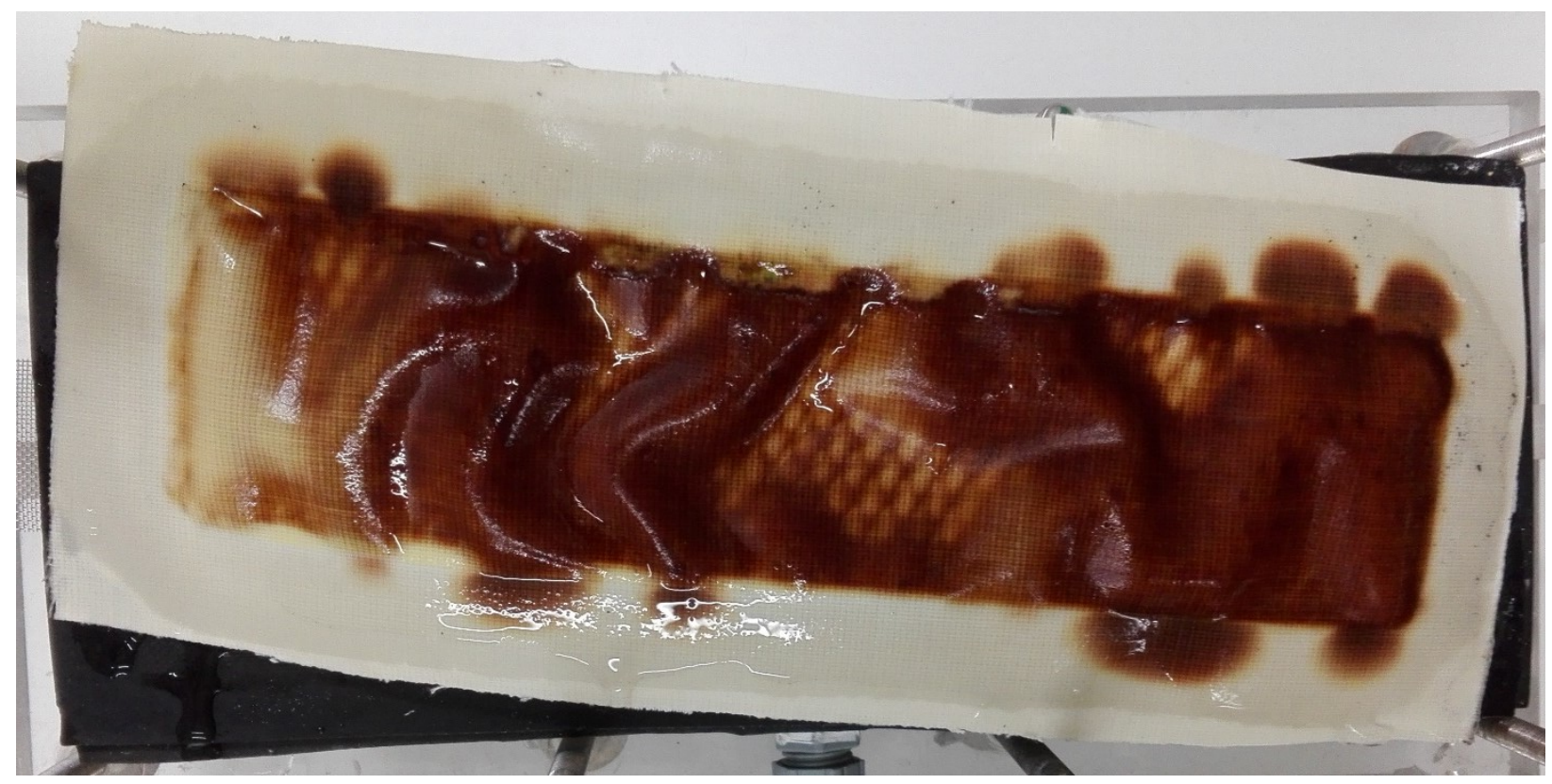

Figure S6. Anion exchange membrane after two days of operation. 


\section{E. Long-term stabilization}

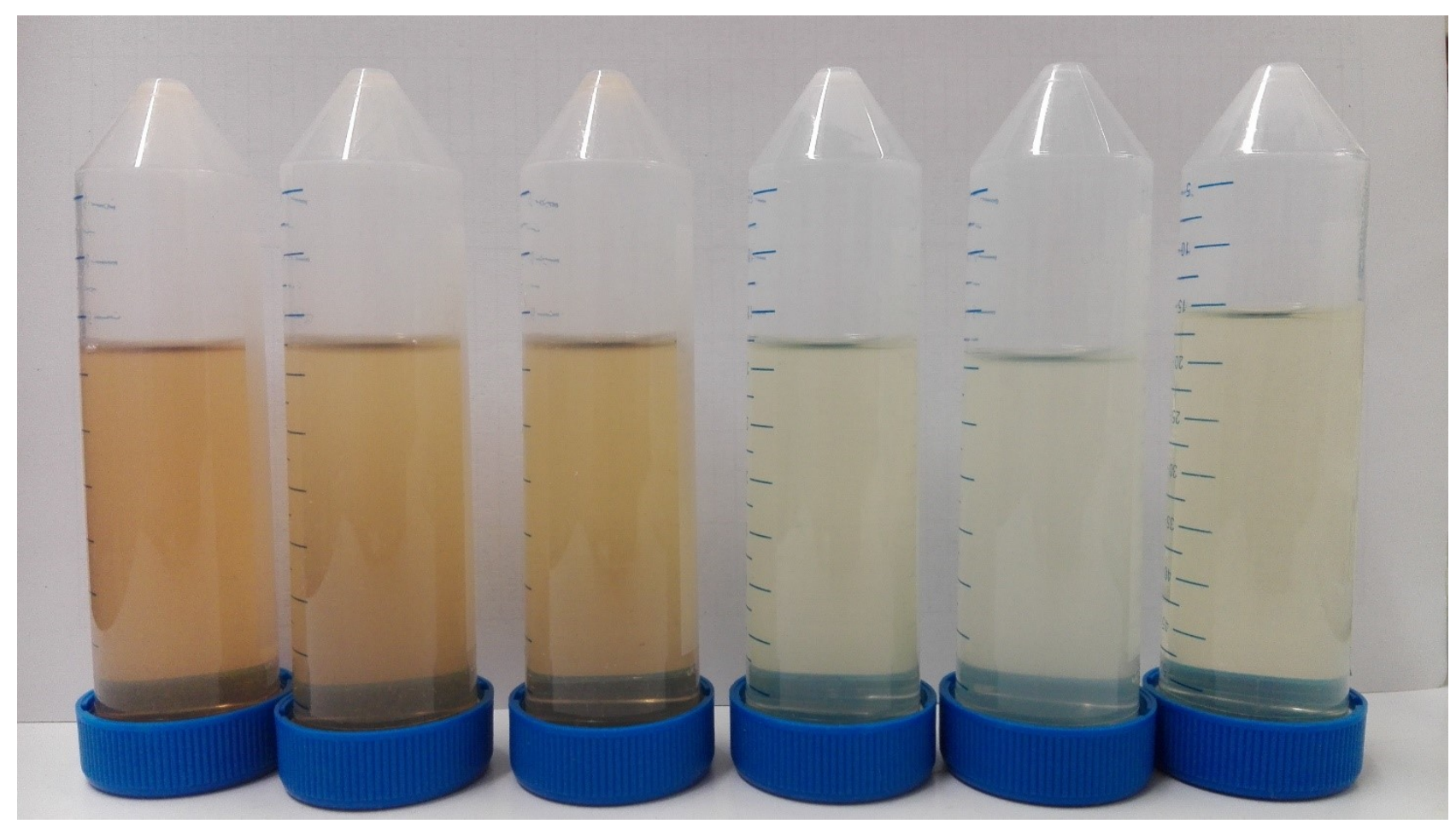

Figure S7. Falcon tubes with non-stabilized urine (left) and stabilized urine (right)

Table S4. Total nitrogen (TN) concentration and total ammonia nitrogen (TAN)/TN ratio in the effluent of the AEM+CEM tests (pH 12) after 0, 561 (before urease addition), 563 (after urease addition) and 568 days. The test was performed in triplicate (' 1 ', '2' and 3').

\begin{tabular}{lccc}
\hline & 1 & 2 & 3 \\
\hline TN [mmol N/L] & 260 & 147 & 194 \\
TAN/TN [\%] (day 0) & 5.3 & 6.4 & 4.8 \\
TAN/TN [\%] (day 561) & 7.8 & 8.4 & 7.3 \\
TAN/TN [\%] (day 563) & 79.5 & 99.7 & 92.2 \\
TAN/TN [\%] (day 568) & 84.6 & 102.2 & 100.8 \\
\hline
\end{tabular}




\section{F. Phosphate removal}

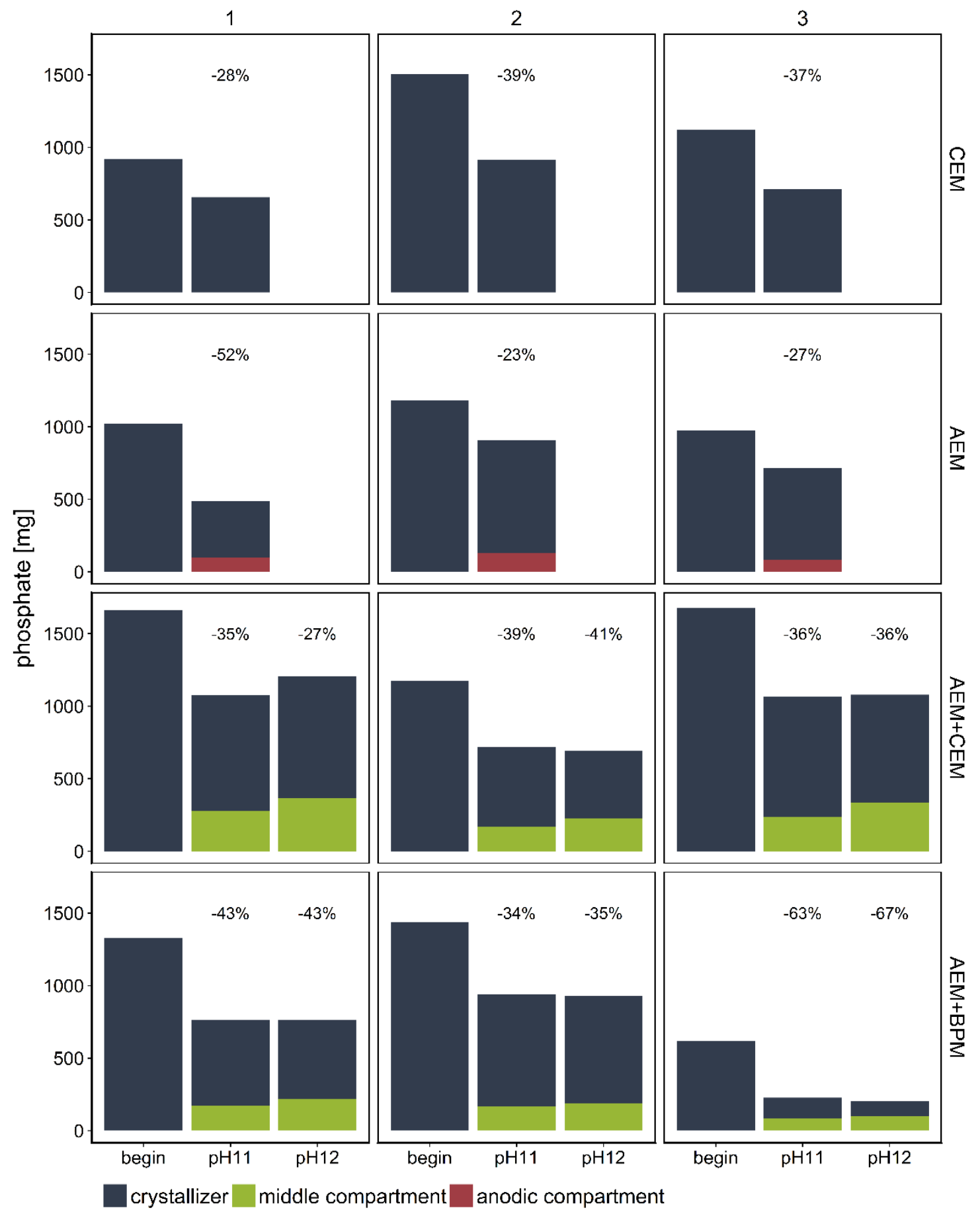

Figure S8. Mass of phosphate in the crystallizer, middle compartment and anodic compartment at the start and end (pH 11 and/or $\mathrm{pH} 12)$ of each experiment. At the start of the experiments, all phosphate was present in the crystallizer. Over the course of the experiment, some phosphate migrated through the AEM to the anodic compartment (AEM configuration) or to the middle compartment (AEM+CEM and AEM+BPM configuration) and some phosphate precipitated in the crystallizer. The percentages represent the decrease in total mass due to precipitation. Each configuration was tested in triplicate (' 1 ', '2' and ' 3 '). 